\title{
I the Supreme Writer of the Republic
}

\section{Yo el Supremo Escritor de la República}

\section{Armando Romero ${ }^{1}$}

This essay intends to interpret the novel Yo El Supremo (I, The Supreme, 1974), Augusto Roa Bastos's masterpiece, taking into consideration first and foremost the importance of the act of writing itself and, subsequently, that of the writer, seen as the new magician of our times and whose activity is meant to uncover the hidden depths of reality - and of the previous meanings of literature as well. The modern writer's ontological tragedy is related to the revelation of the duality/identity implied in the simple act of contemplating oneself in the mirror: "Je est un autre," as Arthur Rimbaud said. Generally understood as a complex (and somehow Baroque) dialogue of the contraries, Roa Bastos's work is not only a novel describing the reality and horrors of the dictatorship, but also a deep and lucid meditation on human nature and on the nature of literature as well. Of course, in many pages the reader may recognize characteristics of Paraguay's dictator José Gaspar Tomás Rodríguez Francia, but the book is capable of exorcizing all its demons. Thus the great surprise of this text consists in its layered construction and in its elaborate literary dialogue with the masterpieces of some great Latin American predecessors. [Article copies available for a fee from The Transformative Studies Institute. E-mail address: journal@transformativestudies.org Website: http://www.transformativestudies.org (02019 by The Transformative Studies Institute. All rights reserved.]

KEYWORDS: Latin American novel, writer, writing, identity, duality, mask, literary dialogue.

\section{A MANERA DE INTRODUCCIÓN QUE NO JUSTIFICACIÓN}

Son éstos algunos apuntes sobre Los apuntes. Son la visión del escritor que hay en mí sobre el escritor que esta allí, aquí. Será un mirarse a la

\footnotetext{
${ }^{1}$ Armando Romero. Biography available at end of article. Address correspondence to: Armando Romero; e-mail: armando_romero@msn.com.
} 